\title{
A BSC- EFQM method for evaluating and detecting performance measurement criteria: A case study of Malavan Footbal team
}

\author{
Heydar Shojaee Vazhnani*
}

Masters Student in Business Management, Department of Management and Accounting, Payame Nour University, Tehran, Iran

\begin{tabular}{|c|c|}
\hline$\overline{C H R O N I C L E}$ & A B S T R A C T \\
\hline $\begin{array}{l}\text { Article history: } \\
\text { Received May 1, } 2013 \\
\text { Received in revised format } \\
\text { 10 July } 2013 \\
\text { Accepted } 3 \text { August } 2013 \\
\text { Available online } \\
\text { August } 52013 \\
\text { Keywords: } \\
\text { EFQM } \\
\text { BSC } \\
\text { Performance measurement }\end{array}$ & $\begin{array}{l}\text { This paper presents an empirical investigation to find important criteria for performance } \\
\text { measurement based on two methods of balanced score card (BSC) as well as European } \\
\text { Foundation of Quality Management (EFQM) methods. In order to determine the mission, } \\
\text { vision, strategy and values we first review different documents including International } \\
\text { Federation of football documentations, AFC and Football Federation of the Islamic Republic of } \\
\text { Iran and Charter Club. Next, we determine the necessary criteria for performance measurement } \\
\text { using interview with decision makers, design a questionnaire and distribute it among } 57 \text { players } \\
\text { and coaching staff as well as experts, veterans and supporters club. Next, we study the results } \\
\text { using t-student test and analyze them. The results are categorized in terms of four criteria of } \\
\text { BSC method including internal processes, learning and growth, costumer and financial. In } \\
\text { addition, key performance results based on the Excellence Model are classified according to } \\
\text { nine areas of leadership, strategy, human resources, partnerships and resources, processes, } \\
\text { customer results, human resource results and society. }\end{array}$ \\
\hline
\end{tabular}

(c) 2013 Growing Science Ltd. All rights reserved.

\section{Introduction}

Performance measurement is one of the most popular methods for having an idea on how well a business unit works. There are literally tens of methods for measuring the relative performance of business units such as data envelopment analysis, balanced score card (BSC), European foundation of quality management (EFQM), etc. BSC has been considered as one of the most popular techniques introduced by Kaplan and Norton $(1996,2000,2002,2004)$. The idea of BSC is to measure the performance of a firm based on financial figures along with three other figures including internal processes, learning and growth and customer perspectives. The method has been widely implemented among many researchers and business owners to carefully investigate a business model based on different factors. Mozaffari et al. (2013), for instance, designed performance evaluation system of Islamic Azad University of Semnan by the utilization of strategy map as a prominent part of BSC.

*Corresponding author. Tel: +982188635450

E-mail address: soroosh17@yahoo.com (H. Shojaee Vazhnani)

(c) 2013 Growing Science Ltd. All rights reserved.

doi: $10.5267 /$ j.ms 1.2013 .08 .006 
Valashjerdi Majd Abad Kohneh et al. (2013) performed performance measurement in governmental agencies using BSC-AHP. According to Danaei and Hosseini (2013), strategic assessment of the organizational performance in the industrial environment is one of the primary and essential prerequisites for developing improvement plans in organizations. This issue is so important that one of the on-going affairs in the firms is to detect the weakness and strength points. Danaei and Hosseini (2013) implemented BSC to design a questionnaire and distributed it among 31 managers, 94 regular employees and 110 customers of an Iranian firm for the fiscal year ended 2011. The results of their study indicated that the firm could reach $41.4 \%$ of its financial objectives, $87.38 \%$ of its customers' requirements, $66.13 \%$ of internal processes and $70.94 \%$ of its learning necessities according to four major BSC requirements.

Khosravi et al. (2013) used BSC for performance measurement based on four different perspectives including internal process, learning and growth, customer and financial performances. For each perspective, the proposed study used analytical hierarchy process to rank various sub-criteria. They reported that profit margin was the most important item followed by profit capability and brand name while productivity and sales force performance were the least important items. Dabaei and Omidifard (2013) presented a study to measure the performance of a mining firm in province of Semnan, Iran based on BSC. They investigated the present status of the case study in terms of four BSC perspectives including internal process, learning and growth, customer and financial figures.

According to Shojaee et al. (2012), tangible assets used to be the most important precious wealth of organizations. However, the recent advances in technology has changed this concept and today, intangible assets such as human resources, customers, processes are playing critical roles on making strategies. Shojaee et al. (2012) presented a study to setup appropriate strategies by implementing BSC in four perspectives of customers, processes, learning and financial. They gathered important factors through three brainstorming sessions and prioritized them based on TOPSIS method. Based on the results of MCDM technique, selecting appropriate target market for penetration was the number one priority followed by having good accounting system and preparing for more diversified production. These were the most important items impacting strategic planning. Therefore, the study implemented BSC for the first two important strategies and discusses possible actions for productivity improvement.

European Foundation Quality Management (EFQM) is one of the most popular methods for measuring performance of organizations. Abbasi and Farhangi (2013) performed an empirical survey to customize EFQM method for broadcasting organization of Iran. They analyzed and assigned some points to various criteria and realized that standard EFQM could be considered as a customized method for taking appropriate strategies in this organization.

\section{The proposed study}

We present an empirical investigation to find important criteria for performance measurement based on two methods of balanced score card (BSC) as well as European Foundation of Quality Management (EFQM) methods. In order to determine the mission, vision, strategy and values we first review different documents including International Federation of football documentations, AFC and Football Federation of the Islamic Republic of Iran and Charter Club. Next, we determine the necessary criteria for performance measurement using interview with decision makers, design a questionnaire and distribute it among 57 players and coaching staff as well as experts, veterans and supporters club. Next, we study the results using t-student test and analyze them. The results are categorized in terms of four criteria of BSC method including internal processes, learning and growth, costumer and financial. In addition, key performance results based on the Excellence Model are classified according to nine areas of leadership, strategy, human resources, partnerships and resources, processes, customer results, human resource results and society. These results are presented in the next section. 


\section{The results}

\subsection{The first objective}

In first objective, we have asked decision makers about different actions, which could help team management improve their skills on developing human resources to have key players. Table 1 demonstrates the results of our survey on this item and the results indicate that all items are considered important for improving skills.

\section{Table 1}

The results of $t$ student values for the first objectives

\begin{tabular}{ll}
\hline Item & $\mathrm{t}$ \\
\hline Establishing academy football club & 8.090 \\
\hline Funding basic research and education for every player in each category & 6.625 \\
\hline Inviting domestic teachers to attend the training and mentoring teams for team & 8.604 \\
\hline Inviting international instructors for the training of first class coaches and club teams & 8.687 \\
\hline Attending domestic coaches in international short courses to upgrade their knowledge & 7.643 \\
\hline Attending domestic coaches in domestic short courses to improve their skills & 9.762 \\
\hline Training programs for team players using domestic coaches & 8.101 \\
\hline Guiding university research projects to contribute to team & 8.463 \\
\hline Applying digital learning programs to upgrade team's skills & 4.882 \\
\hline Using advanced technical innovations for knowledge improvement & 6.927 \\
\hline Playing partnership role in related conferences & 7.433 \\
\hline Publishing related scientific materials with team's logo & 7.652 \\
\hline Reaching an acceptable rate of international certificates from FIFA and AFC & 9.625 \\
Building social relationship with other teams' managers to improve team leadership & 8.091 \\
Having some good relationships with other well-known teams around the world to exchange experiences & 7.301 \\
\hline Resolving any existing challenges in team & 6.462 \\
\hline Proposing new entrepreneurship programs & 7.867 \\
\hline Increasing the rate of exchange in team's players with other domestic teams & 2.699 \\
\hline Increasing the rate of exchange in team's players with other international teams & 5.092 \\
\hline Increase invitation of domestic experts & 8.235 \\
\hline Increase invitation of other teams' experts & 4.666 \\
Improving quality of team players & 9.101 \\
Increase in the number of first class team & 7.232 \\
\hline
\end{tabular}

\subsection{The second objective}

The second objective of this survey is associated with improving the image of team in country. Table 2 shows details of findings.

\section{Table 2}

The results of $t$ student values for the second objectives

\begin{tabular}{lc}
\hline Item & $\mathrm{t}$ \\
\hline Team players' interest in staying in team & 6.780 \\
\hline Improvement of team's image among coaches & 10.447 \\
Improvement of team's image among players & 8.828 \\
Improvement of team's image among fans & 9.762 \\
Increase in the number of fans & 11.398 \\
Rate of players employed & 9.466 \\
Increase interest in other well-known teams' players in playing in this team & 7.150 \\
The number of team's achievement in play off as well as other competitions & 9.006 \\
The number of times of qualifications in Asia league competition & 8.005 \\
Increase in demands to play in this team & 8.571 \\
Improvement in team's technical skills & 7.756 \\
Improvement in quality of game land, fans, etc. & 7.477 \\
\hline
\end{tabular}


As we can observe from the results of Table 2, all components are considered important and team needs to pay more attention on these issues.

\section{The third objective}

The third objective of this paper is associated with influential items improving profitability of the team such as training as well as research based activities summarized in Table 3 as follows,

\section{Table 3}

The summary of factors associated with financial affairs

\begin{tabular}{lc}
\hline Item & $\mathrm{t}$ \\
\hline Increase in training income & 8.168 \\
\hline Increase in research income & 6.179 \\
\hline Increase in income in exchange player's incomes & 4.763 \\
\hline Income from TV live broadcasting programs & 8.339 \\
\hline Income from ticket sales & 7.141 \\
Increase income in financial supporters and sponsors & 9.766 \\
\hline Increase in advertisement dresses and symbols & 5.000 \\
Cost reduction using fans' free services & 7.577 \\
Increase in people's donation & 5.500 \\
Increase in debts & 4.742 \\
Increase income through consultation with other teams & 6.327 \\
Reduction in fines' expenses & 8.935 \\
Increase in team's winning games & 6.953 \\
\hline
\end{tabular}

The results of t-student values associated with Table 3 indicate that all components are statistically significant $(\alpha=5 \%)$.

\section{The fourth objective}

The fourth objective is associated with efforts on creating sportsmanship as well as friendship behavior among fans. Table 4 shows details of the items related to this topic.

\section{Table 4}

The summary of items associated with for building sportsmanship and friendship

\begin{tabular}{lc}
\hline Item & $\mathrm{t}$ \\
\hline Increase in training programs associated with cultural effects & 8.011 \\
Increase in budget for culture club & 7.977 \\
The amount of advertising in the culture fans & 9.309 \\
Charitable activity & 7.073 \\
Players interact with adults in local media & 6.960 \\
Conferences and meetings between players and fans & 6.139 \\
Improve welfare among fans for close relationship & 5.875 \\
Increased spirit of joy in province & 7.796 \\
Increased spirit of unity and empathy between fans and players & 9.827 \\
Reduce the damage to the stadium and the events surrounding the end of the tournament & 5.195 \\
\hline
\end{tabular}

The items summarized in Table 4 are all statistically meaningful when the level of significance is five percent and they could contribute to increase the spirit of joyful in firm, fans and society.

\subsection{The fifth factor}

The last item is associated with quality improvement in team, fans, society, etc. They survey have gathered various factors and they are included in Table 5 along with t-student values as follows, 
Table 5

The summary of items associated with for quality improvement

\begin{tabular}{lc}
\hline Item & $\mathrm{t}$ \\
\hline Hiring specialized team management & 8.453 \\
Investment in a modern building for headquarter management & 6.423 \\
Increase in players' job satisfaction & 9.760 \\
\hline Hiring, training skilled management & 4.977 \\
The ratio of the number of educational and sports players on educational facilities & 6.442 \\
\hline Increased amenities of coaches & 7.906 \\
\hline Increased amenities of players & 8.692 \\
\hline Improvement in quality of services offered to coaches & 7.852 \\
\hline Improvement in quality of services offered to players & 11.552 \\
Improvement in physical space club & 6.339 \\
Increase in amount of utilization of club physical spaces & 8.951 \\
Increase in access to club facilities & 6.648 \\
Increase in the number of high schools affiliated with team & 6.921 \\
\hline The ratio of a player on coach & 9.631 \\
The ratio of ranked A coaches & 8.062 \\
Development of women's sport in Asia & 8.714 \\
Reduction on the number of files associated with Football Association disciplinary committee & 8.491 \\
Using successful domestic coaches & 5.238 \\
Using successful international coaches & 5.758 \\
Purchase or building private stadium & 5.646 \\
Equipping existing stadium & 7.082 \\
Signing long term agreements between team and players & 7.139 \\
\hline
\end{tabular}

The results of our survey on the last item, quality improvement, have indicated that all items were statistically able to contribute to teams' quality when the level of significance is five percent.

\section{Conclusion and discussion}

In this paper, we have presented an empirical survey on one of Iranian league's teams named Malavan located in north part of the country. The survey has employed two methods of EFQM as well as BSC to find out different factors, which could significantly contribute to team's continuous improvement.

In terms of financial affairs, there are 13 items including increase in training income, increase in research income, increase in income in exchange player's incomes, income from TV live broadcasting programs, income from ticket sales, increase income in financial supporters and sponsors, increase in advertisement dresses and symbols, cost reduction using fans' free services, increase in people's donation, increase in debts, increase income through consultation with other teams, reduction in fines' expenses and increase in team's winning games.

In terms of customers, team players' interest in staying in team, improvement of team's image among coaches, improvement of team's image among players, improvement of team's image among fans, increase in the number of fans, rate of players employed, increase interest in other well-known teams' players in playing in this team, the number of team's achievement in play off as well as other competitions, the number of times of qualifications in Asia league competition, increase in demands to play in this team, improvement in team's technical skills and improvement in quality of game land, fans, etc.

Among other factors such as internal processes as well as learning and growth, the study has detected several factors, which are common with both methods of BSC and EFQM. We hope the results of this survey could contribute to Iranian football league for having more successful international success. 


\section{Acknowledgment}

The authors would like to thank Dr. Mohammad Mehdi Parhizgar and Dr. Mohammad Mahmoudi for providing guidelines in accomplishment of this survey. We are also grateful for constructive comments on earlier version of this paper.

\section{References}

Abbasi, M., \& Farhangi, A.A. (2013). An empirical study of implementation of EFQM method for broadcasting organization in Iran. Management Science Letters, 3(3), 961-966.

Danaei, A., \& Hosseini, A. (2013). Performance measurement using balanced scorecard: A case study of pipe industry. Management Science Letters, 3(5), 1433-1438.

Dabaei, A., \& Omidifard, A. (2013). Strategic planning and performance measurement using balanced scorecard: A case study of Iran Kaolin and Barite company. Management Science Letters, 3(6), $1655-$ 1658.

Kaplan, R., \& Norton, D. (1996). Using the balanced scorecard as a strategic management system. Harvard Business Review (January. February), 74(1), 75.85.

Kaplan, R. S., \& Norton, D.P. (2000). The strategy-focused organization: How balanced scorecard companies thrive in the new business environment. Harvard Business School Press.

Kaplan, R. S., \& Norton, D. P. (2002). Building the balanced scorecard in public sector. Balanced scorecard report from interview with Rick Pagsibigan, September 19.

Kaplan, R. S., \& Norton, D. P. (2004). Strategy maps: Converting intangible assets into tangible outcomes. Boston, MD: Harvard Bus. School Press.

Khosravi Asil, E. Shahraki, A. \& Shahgholian, K. (2013). Ranking critical success factor in chaos management using BSC and AHP method. Management Science Letters, 3(6), 1649-1654.

Mozaffari, A., Kalaei, M., Shahhosseini, M., \& Chaghouee, Y. (2013). A new framework for performance evaluation system using strategy map: A case study of Islamic Azad University of Semnan. Management Science Letters, 3(4), 1041-1048.

Shojaee, M.R., Fallah, M. \& Fallah, M. (2012). A hybrid TOPSIS-BSC method for strategic planning. Management Science Letters, 2(8), 2845-2850.

Valashjerdi Majd Abad Kohneh, A., Oorehee Yazdani, B. \& Kamalian, A. (2013). Performance measurement in governmental agencies using BSC-AHP: A case study of Civil Registry Office in Tehran. Management Science Letters, 3(4), 1255-1260. 